\title{
An ethnographic approach to the reception of telenovelas: some reflections on research methods ${ }^{1}$
}

\author{
Thaïs Machado-Borges ${ }^{2}$
}

\begin{abstract}
Brazilian telenovelas are broadcast throughout Brazil six days a week during prime time. Everyday, they attract an audience of more than forty million viewers. They also attract millions of dollars of advertising revenue and promote a range of commodities and desires that are made available for television viewers. Several studies on the reception of Brazilian telenovelas have considered viewers' reactions to and interpretations of the plots of telenovelas. Having decided to research about the impact these programs have on people's lives, I was confronted with a crucial question: how to proceed in order to obtain qualitative information about the reception of telenovelas? In this article, I discuss and reflect on some methodological questions with which I had to deal during my research process. Here I argue that a complete analysis of viewers' reception of telenovelas should take into account the way telenovelas are integrated and implicated within other media and within events of daily life. Ethnographic fieldwork makes such an approach possible.
\end{abstract}

Key words: telenovelas; reception studies; audience; daily life; ethnography.

Resumo: As telenovelas brasileiras são transmitidas pelo Brasil em horário nobre, seis dias na semana. Elas atraem, diariamente, uma audiência de mais de quarenta milhões de expectadores. Elas também atraem milhões de dólares em receita de publicidade, além de promover uma gama de produtos e desejos que são disponibilizados para milhões de expectadores. Diversos estudos de recepção de telenovelas brasileiras têm considerado as reações e interpretações das tramas apresentadas. Tendo decidido pesquisar o impacto destes programas nas vidas das pessoas, eu fui confrontada com uma questão crucial: como proceder para obter informações qualitativas sobre a recepção das telenovelas? Neste artigo, eu discuto e reflito sobre algumas questões metodológicas com as quais eu tive de lidar durante o meu processo de pesquisa. Eu argumento que uma análise completa da recepção dos expectadores de telenovelas deve levar em conta a maneira como elas são integradas e implicadas dentro de outras mídias e de eventos da vida cotidiana. O campo de trabalho etnográfico torna esta perspectiva possível.

Palavras-chave: telenovelas; estudos de recepção; audiência; vida cotidiana; etnografia.

Television has an indisputable authority in Brazil's cultural scene. Almost 94 percent of the households in the country have at least one television - in sheer numbers, this means 42 million TV households. Even outside the home, televisions are everywhere; in cities it is impossible to pass a street without seeing a shop, a bar, a restaurant or an office with a

${ }^{1}$ Uma versão anterior deste artigo foi apresentada na quarta edição da Conferencia Internacional Crossroads in Cultural Studies, em Tampere, Finlandia, 2002. Originalmente endereçada para leitores estrangeiros, ela contém informações que podem parecer desnecessárias para leitores brasileiros. 
television. Through communication satellites, reception dishes and retransmitting ground stations, television reaches people even in the most remote villages of the country. ${ }^{3}$

Any observer of Brazilian mass media would be able to conclude that watching television is definitively part of the naturalized and maybe even unquestionable practices spread throughout the country. Within this context, the case of Brazilian telenovelas seems particularly interesting. Broadcast six days a week, during prime time, they can be expected to attract a daily audience of more than 40 million viewers (Allen 1995:2).

Telenovelas are able to catch and maintain the attention of a faithful audience throughout six to eight months. Unlike American or British soap operas that may last for several years, Brazilian telenovelas end after 150 to 200 episodes, and are immediately replaced by new ones. Their plots may conform to real-life seasons and holidays, and they often introduce fashions and products, approach polemical subjects, and comment (in a realistic or parodic way) on contemporary social issues.

Telenovelas are a common point of reference among Brazilians: Roque Santeiro ("Roque, the Saint-Maker," written by Dias Gomes and Aguinaldo Silva and broadcast by Globo ${ }^{4}$ in 1985-86), was seen daily by over 70 million people. The characters of Porcina and Sinhozinho Malta became very popular. Porcina, an exuberant and vulgar widow, the fiancée of Sinhozinho Malta, launched a fashion for extravagant dress: pink ribbons, plastic necklaces, scarlet lipsticks, all of which were considered "bad-taste accessories" by specialized fashion magazines, were then presented as being in vogue - "the Porcina Style." A few days after the inauguration of this telenovela, an upsurge of a cold virus was named after Porcina - “one that takes everybody to bed” (Herold 1988).

Popular telenovelas can also stop the country temporally. For instance, in 1990, Rio's carnival parade was delayed by almost one hour because the last episodes of the telenovela Tieta (“Tieta," written by Aguinaldo Silva, broadcast by Globo in 1989-90) were broadcast at the same time the parade was supposed to start. Several newspapers and television programs devoted articles and features to describing how people were captivated by the final episodes

\footnotetext{
2 A autora é PhD., e pesquisadora no Instituto de Estudos Latino Americanos da Stockholm University. E-mail: machado_t@lai.su.se.

${ }^{3}$ These data are based on several studies about Brazilian television (IBGE 2006; Kehl 1986; Mattelart and Matellart 1990; Mattos 1990; Silva 1997; Sodré 1977, 1997), its programming politics, its audience (Fachel Leal and Oliven 1987; Fadul 1993; Girardello 1998; Micelli 1972), and its relation with the state (Kehl 1979; Santos Jr. 1996).
} 
of A Próxima Vítima ("The Next Victim,” written by Silvio de Abreu), another prime-time telenovela broadcast in 1995 by the Globo network. This telenovela had become a hot conversation topic, discussed not only in the intimacy of the family but also in work places, schools, universities, bars and restaurants. The identity of the murderer in this telenovela, to be revealed only in the very last episode, became the motive for many bets among an excited audience. Globo's prime-time news broadcast, the Jornal Nacional, interviewed the author of the telenovela, who explained that many possible endings were filmed and nobody but him knew who the murderer would be. Suspense was unbearable.

All these facts influenced my decision to study telenovelas and make of these programs the subject of my Ph.D. dissertation in social anthropology. I started from a simple question: how do viewers engage with telenovelas' representation of gender, race and class issues? During the course of research this question was both amended and complicated (see Machado-Borges 2003).

In this article, I reflect on some methodological questions with which I had to deal during the process of gathering qualitative material for my work. By discussing some of the methods I used to construct and delimit my field of research, I aim to present a concrete suggestion that illustrates how ethnography ${ }^{5}$ can broaden the perspective of reception studies.

Here I argue that a complete analysis of viewers' reception of telenovelas should take into account the way these programs are integrated and implicated within other media and within events of daily life. Telenovelas should be approached as dynamic cultural products whose retrievability goes far beyond the medium of television. Ethnographic fieldwork makes such an approach possible.

Moreover, ethnography foregrounds telenovela reception as a dialogical process of appropriation, circulation, and reiteration of meaning that is anchored and framed by sociocultural contexts and subjective positions.

\footnotetext{
${ }^{4}$ Brazil's largest television (and media) network and the fourth largest television network in the world.

${ }^{5}$ Ethnography is a particular process of research that "is characterized by an epistemological commitment to explicit and holistic interpretation from a bottom-up perspective, an empirical interest in first-hand exploration and application of multiple, mainly qualitative but also quantitative, methodologies" (Schrøder et al. 2003: 64). Participation, observation and interviewing are some of the methodologies applied in this kind of research process. Contemporary anthropological studies are (with a few exceptions) based on ethnographic fieldwork.
} 


\section{How to Study the Reception of Telenovelas?}

Previous studies on the reception of Latin American telenovelas ${ }^{6}$ have considered viewers' reactions to and interpretations of the plots of telenovelas (Beltrão 1993; Bustos-Romero 1993; Kottak 1990; Munoz 1992; Pace 1993; Quiroz and Márquez 1997; Vink 1988). Such an approach has a well-delineated program and a well-delineated research context, namely, the immediate reception (read interpretation) of telenovela plots.

Media researcher Janice Radway (1988:363) suggested that many researchers of media reception still initiated their

inquiry by beginning with texts already categorized as objects of a particular sort. Audiences, then, are set in relation to a single set of isolated texts which qualify already as categorically distinct objects. ...Such studies perpetuate, then, the notion of a circuit neatly bounded and therefore identifiable, locatable, and open to observation. Users are cordoned off for study and therefore defined as particular kinds of subjects by virtue of their use not only of a single medium but of a single genre as well.

How should researchers proceed, then? In the 1980s and 1990s media researchers turned increasingly towards anthropology and ethnographic methods to better situate their research within complex social contexts. This “ethnographic turn” (Spitulnik 1993) in media studies mirrored a need to actually immerse in the daily practices and social worlds of the people studied, moving towards a deeper social and cultural contextualization of both viewers and media (Abu-Lughod 1989; Das 1995; Fadul 1987; Hannerz 1990; Hirsch and Silverstone 1992; Ginsburg 1998; Kulick and Wilson 1994; McAnany and La Pastina 1994; Tufte 1993; Vilchez 1997). All these discussions on methodology and the use of ethnography to broaden the perspective of reception studies influenced the way I designed my own research questions and methods for data collection. In what follows I present and discuss them.

\section{Research Methods}

Field and Sample

I conducted fieldwork between 1995 and 2000, in the state of Minas Gerais, southeastern Brazil. In 1995, I spent three months in the city of Ouro Preto for a recognition trip. The most

\footnotetext{
${ }^{6}$ Since I am basically retelling the steps of my Ph.D. research (Machado-Borges 2003), I focus particularly on studies about the reception of Latin American telenovelas published before or during the course of my research (1997-2001).
} 
extensive period of fieldwork was in 1997, when I spent six months in the city of Belo Horizonte. After that, I returned to the field for shorter periods (generally a month), once a year.

Born and raised in Belo Horizonte, I came to Europe as a student at the age of nineteen. Several years later, as a Ph.D. student in social anthropology at Stockholm University, Sweden, I decided to return to Belo Horizonte and make it the setting for my research. By choosing to conduct fieldwork at home, I was aware that I would have to deal with previous, biased, subjective knowledge of the field I was about to investigate. How should I handle this issue?

I came to position myself as both an insider and an outsider in relation to my field. How could I ever pretend that I did not know anything about telenovelas? How could I ignore the fact that during my childhood and adolescence I laughed, worried, and talked about these programs, their actors and characters?

I decided to take advantage of my previous knowledge about telenovelas and started asking old friends and acquaintances whether they knew anybody I could interview. I thus used their networks of acquaintances and relatives as informants (this technique is called "snowball sampling”).

Like Brasília, Brazil’s capital, Belo Horizonte was planned and built to become the capital of the state of Minas Gerais. The city was inaugurated in December 1897. It has today a population of approximately three million people. I rented an apartment in a - by local standards - middle-class neighborhood: by coming in contact with my neighbors and by finding ways to participate in the everyday life of the bairro, I recruited a second sample of informants coming from different socioeconomic backgrounds.

During fieldwork, I gathered a total sample consisting of forty-five persons - thirty-eight women and seven men. Thirty-two of them were aged between 14 and 30 years. Informants occupied different social positions: thirteen of them had truly low incomes (about 100 Reais a month, which corresponded at the time to approximately US\$100), three of them came originally from low- income families but had ascended socially and economically, and the rest of them, i.e., twenty-nine persons, had higher educational levels and higher incomes. Besides that, I gathered 183 essays about telenovelas written by undergraduate university students in their first year of communication studies. 


\section{e compós}

www.compos.org.br

I combined two major techniques to collect data: interviews (semi-structured and informal) and participant observation.

\section{Interviews}

During the whole period of fieldwork, I conducted twenty semi-structured interviews, most of them with women (aged 15 to 45). I booked a time and a place, came with my tape recorder and with a list of questions that I intended to ask. This questionnaire was open to modifications and extensions, depending on the answers I got from my informants. The questions I asked were structured around three main topics:

a) Practices of watching and familiarity with the genre - the aim here was to situate telenovela watching within the context of everyday life: what are the informants' favorite telenovelas; how many telenovelas a day do they watch; what leisure occupations do they have; do they comment on the telenovela with others; what is a good telenovela in their opinion; do they think that telenovelas resemble each other; can they recognize a kind of character that appears in most telenovelas; etc.

b) The relationship between fiction and reality, and the reception of the telenovelas' messages - do characters in a telenovela resemble people that the informants know; do the events portrayed in a telenovela resemble events of everyday life; would they like to be characters in a telenovela; etc.

c) Reflections on and representations of gender, race and class - the aim here was to investigate how social hierarchies of gender, race and class are experienced by the informants in their daily lives and how they are portrayed in the telenovelas: what is the sex, age, marital state and class of the interviewees; how do they discuss moral and aesthetic values; what is beautiful and what is not; what is good or bad taste; what are their fears and aspirations; notions about "good” and "bad," "right” or “wrong," "happiness," etc.

All these interviews were tape recorded and transcribed. Even though these interviews were important for my material, since they made people talk almost exclusively about subjects of my own choice, I felt that my informants were giving official answers to the questions I asked, as if there were a right or even politically correct way to respond. Many times, what people told me when the tape recorder was on, contradicted totally what they had previously said, in a more informal situation.

My first attempt at an interview is a good illustration of that: I asked the owner of a tiny and very simple beauty parlor whether she watched any telenovela, and she answered, "No, I 
don't have time to watch any novelas.” As she was explaining why she didn't have the time to watch telenovelas, she started to dust a huge television set placed right in the middle of the tiny room. As she noticed that I was eyeing the big television set, she told me: "Oh, yes, I have this television here. But I hardly watch it. It’s just for my clients...”

I noticed a gap between what people said about their daily practices and habits concerning television watching and what they actually did.

\section{Participant Observation}

Participant observation, anthropology's most important research method, involves both the direct participation of the researcher in the event she or he is studying, and reflective observation of what is going on. In my specific case, participant observation was a way to get access to the moments when telenovelas spontaneously intersected with viewers' everyday lives. It was also a way to get access to tacit, "obvious," and unspoken meanings which did not emerge from interview situations.

Influenced by an anthropological understanding of media, dismayed by the uniform answers I obtained through interviews, and convinced by the argument that reception practices are not confined to the moment of broadcast (Grossberg 1987; Miller 1995; Silverstone 1994; Spitulnik 1997), ${ }^{7}$ I decided to focus on a broad understanding of reception, and set out to examine how viewers incorporated telenovelas to their habits and daily practices. More precisely, I decided to investigate when, why and how themes related to telenovelas spontaneously came to the fore in everyday situations. By taking such a standpoint, I moved my focus away from the moment of broadcast (or from "immediate" reception and interviewing) to streets, parties, and everyday conversations and interactions.

This choice of focus made me realize that for the most part, commentaries and references to telenovelas were fragmented and mixed with other topics and thought associations - an event taking place in a telenovela could trigger a discussion about an everyday, "real-life»"

\footnotetext{
7 'Media reception occurs 'beyond the living room' and media production 'beyond the studio' not only because they occur in places like the Amazonia rainforest or the Australian outback but because, as Roger Silverstone notes, regarding television watching, for example, they occur as part of 'a set of daily practices and discourses...through which that complex act is itself constituted (1994:133)" (Ginsburg et al. 2002:I).

${ }^{8}$ The expression "real life," in Portuguese, vida real, is frequently used in everyday talk about telenovelas. "Real life" and "telenovela" are used as opposites and stand for the binary "reality" and "fiction." For instance, I could hear people say: "In real life, the actor Tony Ramos is married." This expression, used to emphasize a contrast between everyday life and the fictive world of telenovelas, is
} 
subject. Telenovelas' landscapes, characters, names and persons could be used to comment upon real events, places and persons. And, the other way round, everyday events could lead to associations about fictive characters and situations.

Moreover, I could observe that not only did viewers talk about telenovela plots, their contents and characters, but they also talked extensively about subjects and products that derived from or somehow intersected with the telenovela plot. The extract quoted below is a typical illustration of how informants spontaneously talked about telelenovelas.

I was talking to Maria do Carmo, a 55-year-old woman who worked as a staff administrator at a governmental office; her mother, Dona Juraci, a 75-year-old housewife; and Vera, a 40-year-old manicurist.

Maria do Carmo had three grown children from her first marriage and she was now married to Altair, a 60-year-old engineer at a governmental office. Dona Juraci was recently widowed. Vera was married but had no children. As we talked, Maria do Carmo played solitaire, her mother mended a dress and Vera peeled some potatoes for dinner: ${ }^{9}$

(1)Dona Juraci (DJ): Today, with this weather, the only thing you can do is watch television.

(2)Maria do Carmo (MC): The only thing I like to watch on television are the films. I don’t like anything else.

(3)Vera (V): Me too. I only watch films and novelas.

(4)MC: I like to watch the beginning and ending of novelas. I watch the beginning to see how it's going to be, and then I watch the ending.

(5)DJ: I don't like the beginnings. I prefer when things are already happening (Gosto mais quando já está mais adiantada).

(6)MC: No. I like beginnings.

(7)DJ: Take this seven o'clock novela [Salsa and Merengue, broadcast in 1996-97 by Globo]. So much rubbish! Can you imagine that they were having a wake for a pair of shoes? What nonsense!

(8)MC: What? I'm not following that novela!

also used to refer to viewers' own experiences and it is synonymous with "everyday life.” A comment made by one of my informants illustrates that: "We watch this program and we laugh so much: 'Oh, those people are crazy!' Then, we suddenly realize that real life is exactly the same thing. Then we don't laugh as much, anymore.” 
(9)V: Oh! It was funny. They were having a wake for Dona Imaculada [a character in the telenovela]. They thought a train had run over her and they were having a wake for her shoes. The only thing they found left after her.

(10)DJ: How silly! (Que bobagem!)

(11)V: Well, I thought it was funny. Then suddenly Dona Imaculada appears at the wake and everybody looks so stupid...But I don’t like Heitor.

(12)MC: Who’s Heitor?

(13)V: That blond guy. He and another guy are involved with the worst criminality. All the time, one trying to stab the other's back (querendo furar o olho do outro). Even that Portuguese guy is involved.

(14)MC: The father as well or just the son?

(15)V: No, only the son.

(16)DJ: Who? The Portuguese?

(17)MC: Yes, that handsome young man.

(18)V: Oh, I think he is so handsome!

(19)DJ: But the father is handsome, too.

(20)V: Yes! It's the father I’m talking about! An old hunk! (Um coroaço!)

(21)MC: Another one who is also getting older but doesn't appear to, is that Tony Ramos [an actor who was playing the main part in Globo's six o'clock telenovela in 1996-97].

(22)DJ: Hm, but he had to lose weight to play this character in the novela.

(23)MC: I read that he went to one of those spas to lose weight. But you know, in a spa, besides all the exercise they do, they present diet food in a very pleasant way. You actually feel like eating it. It's not the same sacrifice that we do when we go on a diet at home. If I had the money I'd go to one of these spas to get in shape. Yes. It's really a nice thing.

(24)DJ: I bet he’s already done some plastic surgery too.

(25)V: That's for sure!

\footnotetext{
${ }^{9}$ This conversation is reconstructed from my field notes. I use pseudonyms instead of actual names.
} 


\section{e compós}

www.compos.org.br

(26)MC: Like that cousin of mine - Marlene. Her husband gave her a facelift as an anniversary present. And now she wants to do a lipo [liposuction] on her belly. To get thin.

(27)DJ: Yes, but her husband said that he won't pay for this one.

(28)MC: She's going to sell her car to have it done. Maybe she’s already done it...

This exchange was one of the many conversations in which I gleaned how informants, in their everyday lives and outside the context of immediate reception, commented on and related to telenovelas.

The extract above shows how the subject of telenovelas is approached in an unframed way, without requiring detailed explanations or contextualizations (line 7): talking about telenovelas, their characters and actors was a good, quite neutral discussion topic, based on commonly shared knowledge about actors and actresses, or about the events in a plot. Dona Juraci need not mention the name of the channel that is broadcasting the telenovela about which she is talking, or even the name of the telenovela itself. It is understood, from the way she refers to the telenovela as "the seven o'clock novela" that it is Globo's telenovela. ${ }^{10}$ To an outsider who has never watched a telenovela in her life, many of the passages I mentioned above, and others that I have registered, would certainly have little or no meaning at all.

The talk of the three women indicates, moreover, that there is a general knowledge among viewers about the structure and rhythm of telenovelas (lines 4, 5 and 6). Those viewers who prefer the telenovela when it has already started are probably fonder of following the intrigues and complications of each sub-plot. Those viewers who, like Maria do Carmo, prefer beginnings and endings of telenovelas are probably more interested in following a faster succession of events. The beginnings of telenovelas are generally quite eventful, since they introduce a sequence of main problems and plots to viewers. Endings are also eventful, since they are the occasion when solutions are given to most problems.

But why would a person who has not been assiduously watching a telenovela want to see its end? How would s/he understand anything? These questions can be answered from different and complementary points of view. As the conversation with Maria do Carmo

\footnotetext{
${ }^{10}$ During the last two decades (but mostly during the 1980s) Globo was the only channel to broadcast several prime-time telenovelas (at approximately six, seven, and eight o'clock). There were other networks, in 1997, that were expanding their production of telenovelas, but generally, when people
} 
shows, even someone who claims not to follow a telenovela seems to know a great deal about its plots and characters (lines 11-17). One could assume that Maria do Carmo, just like many others of my informants, associated the practice of watching telenovelas with non-prestigious age, gender, or class. By denying her interest in following the plot of telenovelas, she could be distancing herself from a low-prestige activity supposedly carried on by people who occupy low-prestige positions. ${ }^{11}$ One could, on the other hand, take Maria do Carmo's comments as evidence of the retrievability of the telenovelas: she does not have to assiduously watch the plot of a telenovela in order to understand what is going on in it. She obtains information about the plots of telenovelas through other texts and contexts, such as magazines, advertisements and casual conversations.

Dissected into several pieces, this example illustrates, moreover, how a conversation about telenovelas can lead to other associations and conversation topics (lines 23 and 26), such as commentaries about telenovela actors, opinions about spas, diets and plastic surgery. Telenovelas could be used as a catalogue of images, names, persons and events to which one could refer in order to comment upon "real-life" events, places and persons.

Ethnography on the "ever-evolving kaleidoscope of daily life and the way in which the media are integrated and implicated within it” (Radway 1988:366) foregrounded that informants experienced telenovelas not as a delimited and circumscribed narrative but rather as a flow, with innumerable articulations and connections. In my Ph.D. dissertation I call this flow of articulations the "telenovela flow."12

\section{Complementary Methods: Structured Conversations and Essays}

In the last months of fieldwork, I decided to insert my previous interview questions into informal situations and conversations. The idea was that people would thus talk in a more spontaneous and informal way about subjects which were directly related to my research interests. Using this technique, I came to gather many "structured conversations” on the most

referred to telenovelas as the "six-, seven- or eight-o' clock novelas" they were referring to Globo's productions.

${ }^{11}$ Most of my informants were immersed in a discourse about the negative effects of television upon unprepared viewers, and associated telenovelas with two particular definitions of popular culture: telenovelas were seen either in contraposition to high culture (and thus understood as vulgar, shallow, low culture), or as being part of a commercial, mass culture. By affirming that watching telenovelas was not part of their own interests, informants positioned themselves as active and selective viewers.

${ }^{12}$ I argue that viewers engage with the telenovela flow as a means to position themselves as subjects within the Brazilian society. 
varied subjects. I also applied this method with some of the persons I had interviewed previously, since I had kept in contact with them through my daily routine. These structured conversations, combined with participant observation, contain, in my opinion, much of my best information.

Finally, in 2001, I asked a teacher at a private university in Belo Horizonte to ask her undergraduate students in communication to write an essay about telenovelas. I suggested three themes from which they could choose: "Telenovelas: Education, Alienation or Plain Entertainment?” (Novelas: educação, alienação ou só diversão?); “Telenovelas: Brazil on the TV screen?” (Novelas: Um Brasil na TV?); "Should Beauty be Exposed? Bodies and Eroticism in Telenovelas” (O que é bonito é para se mostrar? Corpo e erotismo nas novelas). I also asked them to write down their age, occupation, and their parents' occupation. ${ }^{13}$ I obtained a total of 183 essays written by 107 women and 76 men, aged between 17 and 40 years, with a majority aged between 18 and 22. These essays helped me to investigate whether the analysis of my qualitative material could be extrapolated to a larger group of people.

\section{Going with the Telenovela Flow}

Parallel with participant observation, interviewing and structured conversations, I decided to investigate how other television programs, advertisements, magazines and commodities intersected with telenovelas.

Through participant observation, I noticed for instance, that other television programs commented upon the events taking place in a popular telenovela, had telenovela actors as special guests, or, depending on the program, approached the same themes discussed by a telenovela. TVGlobo was the principal commentator on its own telenovelas: during my fieldwork, this network broadcast at two p.m., six days a week, a program called "Video Show." In this program, actors and actresses were interviewed about their private lives and about their telenovela characters. Old pieces of telenovelas, backstage scenes and stunt techniques were shown.

I also observed that many television advertisements had as their main protagonists actors and actresses who were generally playing important roles in one of the several broadcast telenovelas. More rarely, but not uncommon, there were advertisements where the main

\footnotetext{
${ }^{13}$ The most popular theme among these students was "Telenovelas: Education, Alienation, or Plain Entertainment?" followed by "Telenovelas: Brazil on the TV Screen," and, finally, "Bodies and Eroticism in Brazilian Telenovelas.”
} 


\section{e compós}

www.compos.org.br

protagonist was a telenovela character, selling a product connected to his/her role in the telenovela (Machado-Borges 2007).

Looking at other media, I was not surprised to find innumerable references to telenovelas: there were the specialized gossip magazines, with interviews and speculations about the private life of real or fictive persons. There were also fashion magazines showing the latest and hottest telenovela fashion, and weekly newsmagazines which incessantly approached the same themes discussed in these programs.

In the streets, there were outdoor advertisements for various products that had previously been introduced to the public by telenovelas, or that were being introduced by means of a telenovela actor/actress. These products were of course available in most stores, where one could once again find another reference to the world of telenovelas.

I thus noticed that telenovelas were connected to other television programs, other kinds of media such as newspapers and magazines, advertisements, and products one could actually buy in the market. One example will illustrate these articulations.

Scarlet (played by the actress Luiza Tomé) was one of the main characters in the telenovela A Indomada ("The Untamed Woman," Globo, 1997). In the plot, Scarlet represented a modern, open-minded and sexually liberated woman. Scarlet's favorite subjects were sex and seduction, and it was also through sex and seduction that she exerted power upon her husband. Scarlet won the audience's sympathy, and the importance of her character increased in proportion to her popularity. Some expressions that were currently used by Scarlet in the telenovela - such as é um must! ("It's a must!”), or the verb nhanhar, used exclusively by Scarlet and her husband and meaning "to have sex" - started being used by telenovela viewers in their ordinary conversations.

Luiza Tomé, the actress who played Scarlet, became very popular thanks to her character. She was invited to several talk shows where she was interviewed and asked to give her opinion on the most varied subjects. Luiza Tomé appeared in several fashion magazines where she talked about sexuality (hers and Scarlet's), her gymnastic program, her diet, etc.

A television advertisement (it is unclear whether its main protagonist was the actress Luiza Tomé or the character Scarlet), promoted a shoe store named Scarlett. Billboards with the same advertisement were spread all over town. Finally, one might also happen to pass by this very same shoe store, and in its window one would once again see the picture of Scarlet, from A Indomada. 
This example illustrates the displacement of telenovela messages from the domain of the telenovela itself to other television programs and other media, to commodities one could actually buy, diet and gymnastic programs one could actually follow, and to expressions one could use in daily conversations.

Ethnographic fieldwork contributes here to questioning the idea of a neatly bounded television program - the telenovela - and to emphasizing the dialogic connections and articulations linking telenovelas to other kinds of media and commodities.

\section{A Few Words to Conclude}

A principal goal throughout this text has been to discuss how, in an attempt to grasp and understand people's reception of telenovelas, I moved my research focus away from the moments of broadcast (or from the places where immediate reception took place) to streets, parties, and everyday conversations and interactions. Ethnographic fieldwork allowed me to visualize a crucial - though messy and complex - part of my informants' receptive experience. I proposed the term telenovela flow to describe what viewers were actually relating to. An ethnographic approach contributes, in this sense, to questioning the boundaries of television programs by demonstrating that viewers, outside the context of immediate reception, engage with a flow of articulations that link fiction, reality, and consumption.

Moreover, ethnographic fieldwork enabled me to situate particular events within broader and more complex contexts, and thus bring implicit relationships and associations to the fore. One of the major contributions of this approach lies precisely in the examination of these spontaneous, often implicit, tacit or ignored intersections between everyday life events and the telenovela flow.

Based on a brief description of the methods used to collect information for my Ph.D. dissertation, in this paper I argued that ethnography (combining interviews, "structured conversations," and participant observation) can be a means to broaden the perspective of reception studies, since it takes reception out of the immediate moment of broadcasting and foregrounds how and when media intersects with everyday life. In this sense, ethnography offers a new point of view from which the researcher can consider the question of impact of media messages upon people, since it enables her/him to ask not only "How do viewers interpret what they see?” but also "What do viewers do with what they watch?” 


\section{References:}

Abu-Lughod, L. Bedouins, Cassettes and Technologies of Public Culture. In Middle East Report, 159:7- 47, 1989.

Allen, R. (Ed.). To Be Continued...Soap Operas Around the World. London and New York: Routledge, 1995.

Ang, I. Watching Dallas: Soap Operas and the Melodramatic Imagination. London: Methuen, 1985.

Beltrão, M. S. Interpreting Brazilian Telenovelas. In A. Fadul (Ed.). Serial Fiction in TV - The Latin American Telenovelas. São Paulo: ECA-USP, 1993.

Bustos-Romero, O. Gender and Mass Fiction in Mexico: The Receptors of Telenovelas. In A. Fadul (Ed.). Serial Fiction in TV - The Latin American Telenovelas. São Paulo: ECA-USP, 1993.

Clifford, J. and Marcus, G. Writing Culture: The Poetics and Politics of Ethnography. Berkeley: University of California Press, 1986.

Das, V. Critical Events: An Anthropological Perspective on Contemporary India. Delhi: Oxford University Press, 1995.

Fachel Leal, O. and Oliven, R. A televisão e outras falas: como se reconta uma novela. In Ciências Sociais Hoje: 80-93, 1986.

Fadul, A. Cultura e comunicação: a teoria necessária. In M. Kunsch and A.M. Fernandes (Orgs.). Comunicação, democracia e cultura. São Paulo: INTERCOM/Loyola, 1987.

—_Ed.) Serial Fiction in TV - The Latin American Telenovelas. São Paulo: ECA-USP, 1993.

Ginsburg, F. Institutionalizing the Unruly: Charting a Future for Visual Anthropology. In Ethnos 63(2):173-201, 1998.

Girardello, G.E.P. Televisão e imaginação infantil: histórias da Costa da Lagoa. Tese de Doutorado. São Paulo: ECA-USP, 1998.

Grossberg, L. The In-Difference of Television. In Screen 28(2):28-45, 1987.

Hannerz, U. (Ed.). Medier och Kulturer. Stockholm: Carlsson Bokförlag, 1990.

Herold, C. M. The Brazilianization of Brazilian TV: A Critical Review. In Studies in Latin American Popular Culture 7:45-57, 1988.

Hirsch, E. and Silverstone, R. (Eds.). Consuming Technologies: Media and Information in Domestic Spaces. London: Routledge, 1988.

Hodge, R. and Tripp, D. Children and Television. Cambridge: Polity Press, 1986.

IBGE. 2006. Acesso à Internet cresce mais no Sudeste diz IBGE. In http://ultimosegundo.ig.com.br/mundo_virtual/2007/09/14/ibge_acesso_224_internet_cresce_mais_no _sudeste_1005351.html, accessed in November 07, 2007. 
Kehl, M. R. Novelas, Novelinhas e Novelões: Mil e Uma Noites para as Multidões. In E. Carvalho, M. R. Kehl, S. Naves-Ribeiro (Eds.). Anos 70: Televisão. Rio de Janeiro: Editora Europa, 1979.

.Eu ví um Brasil na TV. In A. H. da Costa, M. R. Kehl, I. F. Simões (Eds.). Um país no ar: história da TV brasileira em três canais. São Paulo: Brasiliense, 1986.

Kottak, C. P. Prime-Time Society - An Anthropological Analysis of Television and Culture. Belmont: Wadsworth Publishing Company, 1990.

Kulick, D. and Wilson, M. Rambo's Wife Saves the Day: Subjugating the Gaze and Subverting the Narrative in a New Guinean Swamp. In Visual Anthropology Review 10:1-13.

Machado-Borges, T. Only for You! Brazilians and the Telenovela Flow. SSSA. Stockholm: Almqvist \& Wiksell International, 2003.

. "Ah, se eu tivesse um par de sapatos Scarlet!" Transgredindo os limites entre telenovela e comercial, realidade e ficção, espectador e consumidor. In Stockholm Review of Latin American Studies. Special issue on Media and Transgression: Brazilian Cases, no. 2: 37-46, 2007.

Marcus, G. and Fischer, M. J. Anthropology as Cultural Critique: An Experimental Moment in the Human Sciences. Chicago: University of Chicago Press, 1986.

Mattelart, M. and Mattelart, A. The Carnival of Images: Brazilian TV Fiction. New York: Bergin \& Garvey, 1990.

Mattos, S. Perfil da TV brasileira. 40 anos de história: 1950-1990. Salvador: A Tarde, 1990.

McAnany, E. G. and La Pastina, A. Telenovela Audiences: A Review and Methodological Critique of Latin American Research. Communication presented at the XXIII Congress of the Latin American Studies Association in Atlanta, Georgia, USA. March 10, 1994.

Micelli, S. A Noite da Madrinha. São Paulo: Perspectiva, 1972.

Miller, D. The Consumption of Soap Opera: The Young and the Restless and Mass Consumption in Trinidad. In Allen, R. (Ed.). To Be continued...Soap Operas Around the World. London and New York: Routledge, 1995.

Morley, D. The Nationwide Audience: Structure and Decoding. London: British Film Institute, 1980.

Munoz, S. Modos de vida y modos de ver. In J. Martin-Barbero and S. Munoz (Eds.). Television y melodrama: Genero y lecturas de la telenovela en Colombia. Bogota: Tercer Mundo Editores, 1992.

Pace, R. First-Time Televiewing in Amazônia: Television Acculturation in Gurupá. In Ethnology XXXII(2):187-206, 1993.

Quiroz, M. T. and Márquez, M. T. Mujeres que la miran y mujeres que son vistas. In E.Verón and L. Escudero Chauvel (Eds.). Telenovela - Ficción Popular y Mutaciones Culturales. Serie Mayor, Colección El Mamífero Parlante. Barcelona: Gedisa Editorial, 1997.

Radway, J. Reception Study: Ethnography and the Problems of Dispersed Audiences and Nomadic Subjects. In Cultural Studies 2(3):359-376, 1988. 
Santos Júnior, Roberto M. Tempo de Antena. Elementos para um debate sobre a democratização e participação na televisão. Dissertação de Mestrado. São Paulo: Escola de Comunicação e Artes: USP, 1996.

Schrøder, K., Drotner, K, Kline, S., Murray, C. Researching Audiences. London: Arnold, 2003.

Silva, Magno L. M. Vidrados em violência: O processo de recepção de imagens violentas da televisão entre adolescentes. Tese de Doutorado.. São Paulo: Faculdade de Educação - USP.

Silverstone, R. Television and Everyday Life. London: Routledge, 1994.

Sodré, Muniz. O Monopólio da Fala. Função e Linguagem da Televisão no Brasil. Rio de Janeiro: Vozes, 1977.

-Telenovela y Novela Familiar. In E. Véron and L. Escudero Chauvel (Eds.). Telenovela Ficción Popular y Mutaciones Culturales, Serie Mayor, Colección El Mamífero Parlante. Barcelona: Gedisa Editorial, 1997.

Spitulnik, D. Anthropology and Mass Media. In Annual Review of Anthropology 22:293-315, 1993.

- 1997. The Social Circulation of Media. Discourse and the Mediation of Communities. In Journal of Linguistic Anthropology 6(2):161-187, 1997.

Tufte, T. Everyday Life, Women and Telenovela in Brazil. In A. Fadul (Ed.). Serial Fiction in TV The Latin American Telenovelas. São Paulo: ECA-USP, 1993.

Vilches, L. La fuerza de los sentimientos. In E.Verón and L.Escudero Chauvel (Eds.). Telenovela Ficción Popular y Mutaciones Culturales. Serie Mayor, Colección El Mamífero Parlante. Barcelona: Gedisa Editorial, 1997.

Vink, N. The Telenovela and Emancipation. A Study on TV and Social Change in Brazil. Amsterdam: Royal Tropical Institute, 1988. 